\title{
Evaluation of Palm Fiber Components as Alternative Biomass Wastes for Medium Density Fiberboard Manufacturing
}

\author{
Abdel-Baset A. Adam ${ }^{1}$, Altaf H. Basta ${ }^{2, a_{\star}}$, Houssni El-Saied ${ }^{2}$ \\ ${ }^{1}$ Nag-Hamady Fiberboard Company, Quena, Egypt \\ ${ }^{2}$ National Research Centre Cellulose \& Paper Dept., El-Behoos Street, Dokki-12622, Cairo, \\ Egypt \\ aaltaf_basta2004@yahoo.com
}

Keywords: medium density fiber-board, date palm components, defibration process, thermal behaviour, UF-fibers interaction, strength properties, water resistance property

\begin{abstract}
This work deals with assessing the date palm component wastes as alternative lignocellulosic material for production of Medium density fiberboards (MDF), in order to establish economic and balance between production/consumer ratio at different provinces rather than Upper Egypt. Palm leaves and palm frond was used as MDF precursors. Different urea formaldehyde (UF) levels (10-14\%/fiber) and pressing pressure (25-35 bar) were applied in this evaluation. The acceptable interaction of palm fibers component with UF was optimized by characterizing its DSC \& TGA, in comparison with commercial used sugarcane bagasse fibers. The promising MDF Panel is obtained from palm frond fibers and its mechanical and water resistance properties fulfill the ANSI standard for high grade MDF wood products, especially on applying UF level $12-14 \%$, and pressing pressure, 35 bar. It is interesting to note that, applying higher pressing pressure together with 12\% UF level provided palm frond-based MDF with static bending properties, higher than commercial Bagasse-based MDF. The insignificant effect of pressing pressure was noticed on water swelling property and free-HCHO of MDF panels. Where, both type of fibers have the same water swelling property (reached $\sim 10 \%$ ), and free$\mathrm{HCHO}$ ( $27 \mathrm{mg} / 100 \mathrm{~g}$ board).
\end{abstract}

\section{Introduction}

In Egypt agricultural wastes accumulate in huge quantities, it reaches about 35 MT/year. Part of this amount is used as animal fodder and to produce energy; as well as in production of paper and engineered wood products (particle and fiber boards). Still large amount of agro- wastes remains unused and it is burned in the open atmosphere causing environmental pollution. In laboratory scale some of wastes were used as filler for rubber composites, carbon materials, and hydrogels for water purification [8,10-14,20,25]. Sugar-can bagasse (SCB) regards the main residue available and used as precursor for production of engineered wood products (particleboards and Medium density fiberboards; MDF) and paper, in Upper Egypt. Our previous work was focused on examining the ability of controlling the steam digestion step; to improve the strength of SCB-based MDF produced [12].

Medium density fiberboards (MDF) and particleboards have replaced the natural wood, and plywood in many furniture applications. MDF is superior to particleboards due to its properties including strength, homogeneity and machining performance [4, 26]. They are also appropriate for interior and exterior construction, as well as in industrial applications. The preparation of particleboards and MDF in mill scale started from about four decades. The possibilities of 
utilizing the available agricultural wastes, (e.g., wheat, bagasse, rice straws, peanut husks, and hazelnut shells), using urea-formaldehyde, melamine-modified urea-formaldehyde, and soybean-pMDI adhesive systems in the production of engineered wood products has sparked attention with many authors [1,3,11,13,14,16,17,19,21,24,27,32,33,46,47]. Other trials in producing green artificial wood were carried out by using HCHO-free adhesive and changing the surface properties of natural lignocellulosic fibres by different grafting techniques [34,38-41], or by in-situ grafting of agro-fibres with the free styrene containing polyester [22]. To improve the water resistance (WA and TS) of wood fibers-based MDF together with limitation of formaldehyde emission of promotion of the quality of the resins, wollastonite and its nanoparticles were used in internal and surface treatments [42-43]. However, surface treatment of MDF by Calcite (100\%), clay (100\%) or mixture of clay/calcite did not cause a significant difference on surface quality [28].

Date palm is a multi-purpose tree; it regards a highly national heritage in many countries. It provides food, shelter, timber products. Because of these qualities, and its tolerance to harsh environmental desert conditions, areas under cultivation have increased tremendously in last decades (Mahmoudi et al, 2008). Egypt is the largest date producing country in the world. In 2012, it produced 1.47 million tones that make $19 \%$ of world dates production. Cultivation of date Palms in Egypt dates backs to thousands of years. Approximately seven million fruiting palm trees are grown in Egypt in the Nile Valley, Sinai and similar areas.

Based on the availability of palm date, as well as the environmental and economic impacts of sugar-cane bagasse from storage processes, the objective of this study is focused on evaluating the interaction of palm component wastes (date palm pruning mixed products, leaves \& frond), with commercial UF to be alternative substrate to manufacture of MDF. The success of this alternative material will be supported by comparing the MDF properties resulted from promising Palm component with that produced from bagasse fiber and the standard specifications [5].

\section{Materials and Methods}

\section{MDF Fibers and board preparation}

Date palm rachises (DPR) were collected from date palm trees grown up at Sinai. The used species is " EL BARMATODA ". DPR were air dried in sun light for 48 hours, and then cut to $25 \times 25 \times 3 \mathrm{~mm}$ chips. These chips were softened by steam in a horizontal digester. The steam pressure was maintained at 7.8 bars for $6 \mathrm{~min}$. then defibrated through ANDRITZ refiner parallel experiments, sugarcane bagasse (SCB) samples were also subjected to the same condition of digestion and refining. The softening fibers were sunlight dried and mixed through laboratory blender with different levels of urea formaldehyde (UF) adhesive (based on oven dry basis) ratios as shown in Table 1. The UF was delivered from Speria Co., with free-formaldehyde (HCHO) $0.18 \%$. The ammonium sulfate (1\%based on UF) was added as hardener, followed by 1 $\%$ paraffin wax (based on dry fibers). The mats were formed and pre-pressed using $400 \mathrm{~mm}$ x400 mm box. Medium density fiberboard (MDF) boards with $12 \mathrm{~mm}$ thickness were made by hot pressing at different specific pressures condition as shown on Table 1 , at $165-170^{\circ} \mathrm{C}$ press temperature. For feasibility application such waste, the average weight of palm fronds and palm leaves in palm waste are estimated and recorded in Table 2.

After open air-conditioning for $24 \mathrm{~h}$, these boards were cut according to standard sawing pattern into test specimens serving for the subsequent determination of basic mechanical and physical properties. Each result recorded in the following Figures is the average of five replicate measurements. 


\section{Fiber analysis and MDF tests}

\section{Chemical analysis}

Parts of Date palm rachises were subjected to mill, using sieve $250 \mu \mathrm{m}$ and $400 \mu \mathrm{m}$, followed by conditioning in polyethylene bags for 12 hours, and labeled to be ready for work. The chemical constituents (e.g., extractives, hollocellulose, $\alpha$-cellulose, lignin and pentosans) were determined by standard methods [30,36,37,44].

\section{Thermogravimetric Analysis(TGA)}

The non-isothermal TGA of the selected representative adhesive systems, was carried out using Instrument SDT Q600 V20 Build 20 module (made at US), under nitrogen atmosphere at a heating rate of $10^{\circ} \mathrm{C} / \mathrm{min}$. The analysis was carried out on adhesive casting films ( 7.032- 9.40 $\mathrm{mg}$ ), and their subjected to heat at temperature range from $\sim 30{ }^{\circ} \mathrm{C}$ to $1000{ }^{\circ} \mathrm{C}$,

\section{TG-curve analysis}

Kinetic studies, based on the weight loss data, were obtained by TG curve analysis. The activation energy against the appropriate order of degradation was evaluated by applying an analytical method proposed by Coats and Redfern (1964) [18] and Basta \& El-saied 2008 [9].

\section{Differential Scanning Calorimetry (DSC)}

Differential scanning calorimetry (DSC) is the thermoanalytical technique used to measure the thermal properties of the investigated adhesive systems, as phase transition and glass transition temperature. This analysis was carried out by employing DSC on the same previous Instrument SDT Q600 V20 Build 20 DSC module (made at US), on the dynamic run, also under nitrogen atmosphere at a heating rate of $10{ }^{\circ} \mathrm{C} / \mathrm{min}$.

\section{MDF Tests}

Different parameters of the MDF making involved different UF level (10-14\%) and pressing pressure (25-35 Kgf/ $\mathrm{cm}^{2)}$ were carried out, as shown in Table 1. The density of MDF was fixed by changing the amount of pressed fibers. The levels of UF were selected to provide MDF of E2 type with free-HCHO not exceed $27 \mathrm{mg} / 100 \mathrm{~g}$ board.

Three-point static bending (modulus of rupture; MOR), modulus of elasticity (MOE), and internal bond strength (IB) tests were performed in conformance with ASTM D1037 and ANSI A208.2 standards [5,6], for MDF panel's requirements for interior uses], using an IMAL IB500 testing machine.

For evaluating the low toxicity of the resulted composites, the perforator method [23] for determination of free-HCHO in composites was carried out.

\section{Statistical Analysis}

The data of the mechanical and physical properties of MDF samples manufactured from bagasse, frond, and mixed frond fibers were subjected to statistical data handling through the TWO WAY (ANOVA) variance analysis by using IBM SPSSV20 software in order to evaluate the significance of the board properties. The statistical analyses were carried out separately for both glue additions and pressing pressure. 
Table 1. Experimental parameters

\begin{tabular}{|c|c|c|c|c|}
\hline \multirow[b]{2}{*}{$\begin{array}{c}\text { sample } \\
\text { code }\end{array}$} & \multicolumn{3}{|c|}{ Additives } & \multirow[b]{2}{*}{$\begin{array}{r}\text { sp. Press. } \\
\mathrm{kg} / \mathrm{cm}^{2}\end{array}$} \\
\hline & $\begin{array}{c}\text { UF \% / } \\
\text { substrate }\end{array}$ & $\begin{array}{c}\text { Had \% / } \\
\text { UF }\end{array}$ & $\begin{array}{l}\text { Wax \% / } \\
\text { substrate }\end{array}$ & \\
\hline fa1 & \multirow{6}{*}{10} & \multirow{6}{*}{1} & \multirow{6}{*}{0.5} & 25 \\
\hline ba1 & & & & 25 \\
\hline fa2 & & & & 30 \\
\hline ba2 & & & & 30 \\
\hline fa3 & & & & 35 \\
\hline ba3 & & & & 35 \\
\hline $\mathrm{fb} 1$ & \multirow{6}{*}{11} & \multirow{6}{*}{1} & \multirow{6}{*}{0.5} & 25 \\
\hline bb1 & & & & 25 \\
\hline $\mathrm{fb} 2$ & & & & 30 \\
\hline bb2 & & & & 30 \\
\hline fb3 & & & & 35 \\
\hline bb3 & & & & 35 \\
\hline fc1 & \multirow{6}{*}{12} & \multirow{6}{*}{1} & \multirow{6}{*}{0.5} & 25 \\
\hline bc1 & & & & 25 \\
\hline fc2 & & & & 30 \\
\hline bc2 & & & & 30 \\
\hline fc3 & & & & 35 \\
\hline bc3 & & & & 35 \\
\hline fd1 & \multirow{6}{*}{14} & \multirow{6}{*}{1} & \multirow{6}{*}{0.5} & 25 \\
\hline bd1 & & & & 25 \\
\hline $\mathrm{fd} 2$ & & & & 30 \\
\hline bd2 & & & & 30 \\
\hline $\mathrm{fd} 3$ & & & & 35 \\
\hline bd3 & & & & 35 \\
\hline
\end{tabular}

fxyf: date palm fronds, $b$ : sugarcane bagasse $x=a$ : resin level $10 \% x=b$ : resin level $11 \% x=$ c: resin level $12 \% x=d$ : resin level $14 \% y=1$ pressed at specific pressure $25 \mathrm{~kg} / \mathrm{cm} 2 y=2$ pressed at specific pressure $30 \mathrm{~kg} / \mathrm{cm} 2 y=3$ pressed at specific pressure $35 \mathrm{~kg} / \mathrm{cm} 2$.

Table 2. UF resin specification.

\begin{tabular}{ccccc}
\hline $\begin{array}{l}\text { Spec. Weight } \\
\text { g/cm3 }\end{array}$ & $\begin{array}{c}\text { Solid content } \\
\%\end{array}$ & $\begin{array}{c}\text { Viscosity } \\
\text { cp }\end{array}$ & $\begin{array}{c}\text { Gel time } \\
\text { Sec. }\end{array}$ & $\begin{array}{c}\text { Free HCHO } \\
\%\end{array}$ \\
\hline 1.275 & 60.55 & 378 & 68 & 0.18 \\
\hline
\end{tabular}


Table 3. Chemical analysis of date palm frond and leaves.

\begin{tabular}{|c|c|c|c|c|}
\hline Test/Material & & $\begin{array}{l}\text { DPR } \\
\text { Frond }\end{array}$ & $\begin{array}{c}\text { DPL } \\
\text { Leaves }\end{array}$ & $\begin{array}{c}\text { SCB } \\
\text { Bagasse }\end{array}$ \\
\hline H.Cell \% & & 69.96 & 42.44 & 74.14 \\
\hline$\alpha$ - Cell \% & & 38.99 & 22.66 & 42.58 \\
\hline Hemi \% & & 30.97 & 18.78 & 31.56 \\
\hline lignin \% & & 18.55 & 25.65 & 18.22 \\
\hline Pentosan \% & & 24.79 & 16.65 & 29.22 \\
\hline Water Ex. \% & & 14.16 & 24.24 & 3.97 \\
\hline Solvent Ex. \% & & 1.6 & 4.95 & 1.82 \\
\hline Total Ex. \% & & 15.76 & 29.19 & 5.79 \\
\hline $\mathrm{NaOH} \%$ & & 29.26 & 57.79 & 34.5 \\
\hline Ash \% & & 5.82 & 5.36 & 2.85 \\
\hline \multicolumn{5}{|c|}{$\begin{array}{l}\text { Cell } \%=\text { holocellulose } \%, \alpha \text {-cell } \%=\alpha \text {-cellulose } \%, \text { Hemi } \%=\text { Hemicellulose } \%, \text { Wate } \\
\text { Solvent Ex } \%=\text { water \& solvent extractives } \% \text { respectively, Total Ex. \% = total Extra } \\
\text { NaOH } \%=\text { solubility in } 1 \% \mathrm{NaOH}, \mathrm{C} . \mathrm{W} \%=\text { Cold water solubility } \% . N . B . \text { Hemicellul } \\
\text { tent } \% \& \text { total Extractives can be calculated as follow Hemicellulose } \%=(\text { H.Cell \%) } \\
\%) \text { and Total Extractives } \%=\text { Water Ex } \%+\text { Solvent } \\
\text { Table 4. Average weight of fresh cut date palm components. }\end{array}$} \\
\hline \multirow{2}{*}{ Test/Material } & Avg. & & DPR & DPL \\
\hline & Weight & & Frond & Leaves \\
\hline Frond with leaves & 2.35 & & 1.45 & 0.9 \\
\hline Moisture content & 50.00 & & 54.00 & $45 \%$ \\
\hline Dry weigh & 1.18 & & 0.67 & 0.50 \\
\hline$\%$ & & & 56.8 & 43.2 \\
\hline
\end{tabular}




\section{Results and discussion}

\section{Characterization of fibers}

The chemical analysis and average weight of palm components were studied to examine their chemical constituents in comparison with sugar-cane bagasse, which is a commercial substrate used in local MDF mill; as well as, to estimate its available as alternative biomass instead of bagasse. Thermal analyses (DSC and non-isothermal TGA) were carried out to examine the interaction of UF adhesive with the foregoing agro-fibers. The importance of chemical constituents depends on the fact that, the relatively higher cellulose content may impart the fiber strength; while the extractives will represent serious influence on the steam digestion process, and consequently MDF produced. Because, steam digestion process regards important step operation in manufacturing process, which facilitates the individualization of the fibers, and enhanced MDF formation. Moreover, the available amount of this waste for MDF production and the positive interaction between fibers and UF during resinification and curing processes are also very required for production acceptable MDF.

The results obtained are illustrated in Tables 3- 6 and Figures 1 and 2. Table 3 shows that, leaves of date palm included higher extractives and lignin content together with lower cellulose and hemicellulose contents compared with palm frond component and SCB. The higher cellulose content together with hemicellulose in case of palm frond will play profound effect on fiber strength and self resinification of fiber during exposing to high temperature and pressure. This observation persuades us to recommend this waste in further work as precursor for production of MDF. Moreover, to exclude the serious problem effect of extractives included the leaf on the machines of steam and fibrilization processes. Also, this view is emphasized from the relatively higher average weight percentages of palm fronds ( $57 \%$ ) than palm leaves (43\%); Table 4.

For application in industrial scale and to reduce the effect of extractives, further study was carried out on possibility of using frond and leaves in blend, as a precursor fibrous of MDF production. To recommend the possible using blend-based fibers, its interaction with UF should be studied, in comparison with both palm frond and bagasse fibers. In this respect DSC and TGA of Fibers-UF samples were studied.

For thermal analysis of resinated fibers, the differential scanning Calorimetry (DSC) and the non-isothermal thermogravimetric (TGA) analyses are shown in Figures 1 and 2; while their calculated parameters are recorded in Tables 5 and 6.

With regard to DSC, Figure 1 shows that, the resinated fibers of palm leaves and frond blend with UF exhibits three peak temperatures like bagasse- UF. While, its DSC profiles exhibit an endothermic peaks at relatively higher temperature $\left(248.99^{\circ} \mathrm{C}, 340.01^{\circ} \mathrm{C}\right.$ and $\left.563.22^{\circ} \mathrm{C}\right)$, than bagasse-UF $\left(226.9^{\circ} \mathrm{C}, 272.0^{\circ} \mathrm{C}\right.$ and $\left.359.2^{\circ} \mathrm{C}\right)$. The $\triangle \mathrm{T}$ value of each peak, which calculated from the peak temperature and onset temperature $\left(T_{P}-T_{0}\right)$, is a measure of curing rate and recorded in Table 5 . Table 5 shows that the thermal curing of palm fibers- UF behaves at lower temperatures than that of the commercial bagasse-UF. The $\triangle \mathrm{T}$ value of $1^{\text {st }}$ peak is about 10.68 ${ }^{\circ} \mathrm{C}$ for the whole palm fibers; while in case of bagasse fiber is $35.1^{\circ} \mathrm{C}$. The relatively lower value of $\triangle \mathrm{T}$ in the case of blending from palm components (palm mix), indicates a higher rate of curing. While, in the case of bagasse-UF, curing is started at lower temperature and gives a higher value of $\triangle T$, which means lower rate of curing. This trend is probably accompanied by shorting the time of penetrating the UF adhesive through whole palm fibers, and weakness the adhesion between the fibers, due to fast the condensation of UF adhesive on fiber surface. This unaccepted trend is reduced on using palm frond, whereas the difference values of onset temperature and peak temperature $(\triangle T)$ are also increased than those observed in bagasse-UF. 
Where, $\triangle \mathrm{T}$ for the main peaks are $47.15^{\circ} \mathrm{C}$ and $76.29^{\circ} \mathrm{C}$; while for bagasse are 35.1 and $36.7^{\circ} \mathrm{C}$.

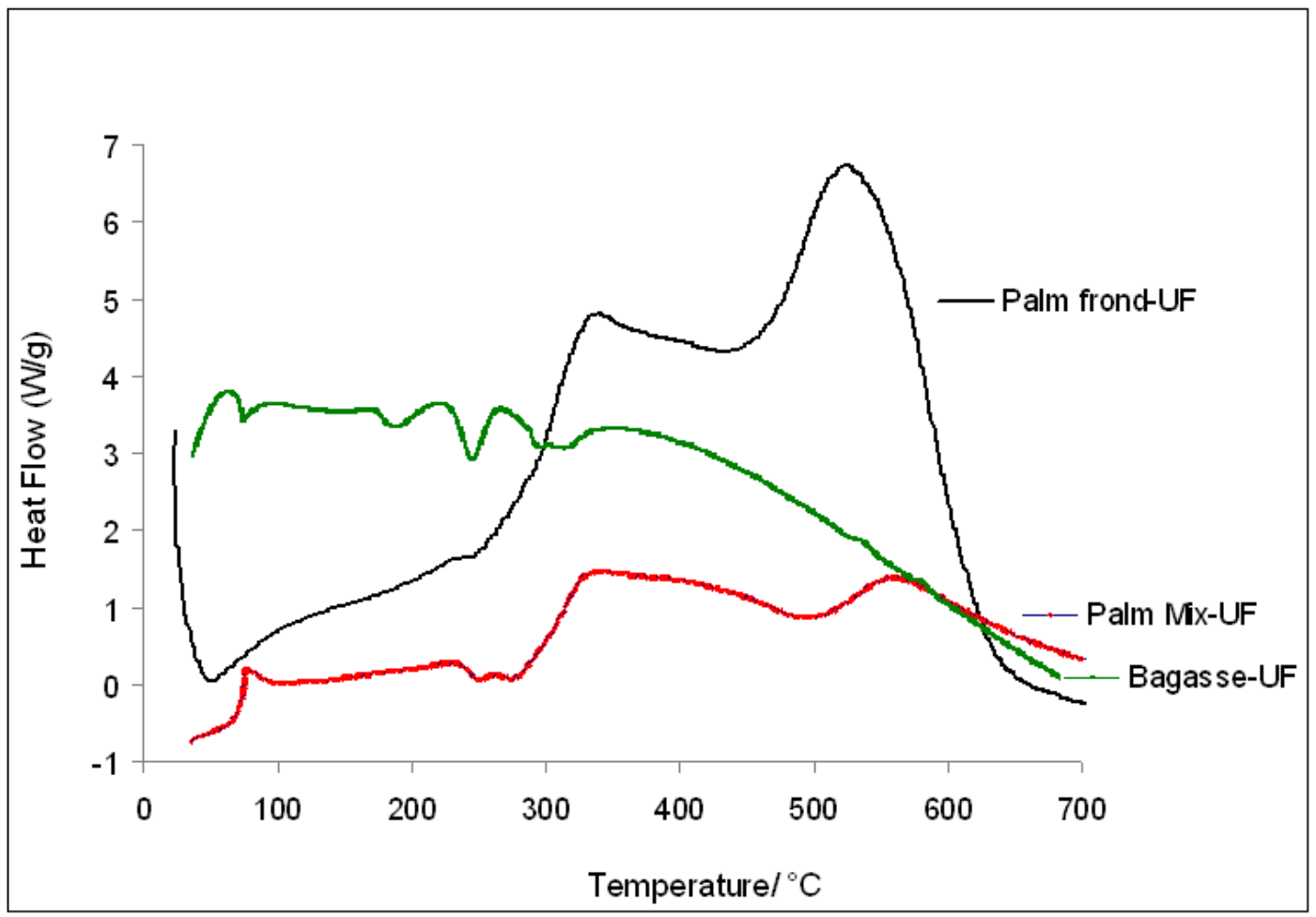

Figure 1. DSC of palm frond fibers with UF in comparison with Bagasse fibers-UF.

Table 5. DSC analysis of the main Endothermic event of Bagasse- and palm components-UF samples.

\begin{tabular}{lcccccc}
\hline & \multicolumn{3}{c}{$\begin{array}{c}\text { First step of curing } \\
\text { reaction }\end{array}$ Sample } & \multicolumn{3}{c}{$\begin{array}{c}\text { Second step of curing } \\
\text { reaction }\end{array}$} \\
\cline { 2 - 7 } & $\mathrm{T}_{\mathrm{o}}$ & $\mathrm{T}_{\mathrm{P}}$ & $\triangle \mathrm{T}$ & $\mathrm{T}_{\mathrm{o}}\left({ }^{\circ} \mathrm{C}\right)$ & $\begin{array}{c}\mathrm{T}_{\mathrm{P}} \\
\left({ }^{\circ} \mathrm{C}\right)\end{array}$ & $\triangle \mathrm{T}$ \\
$\left({ }^{\circ} \mathrm{C}\right)$
\end{tabular}



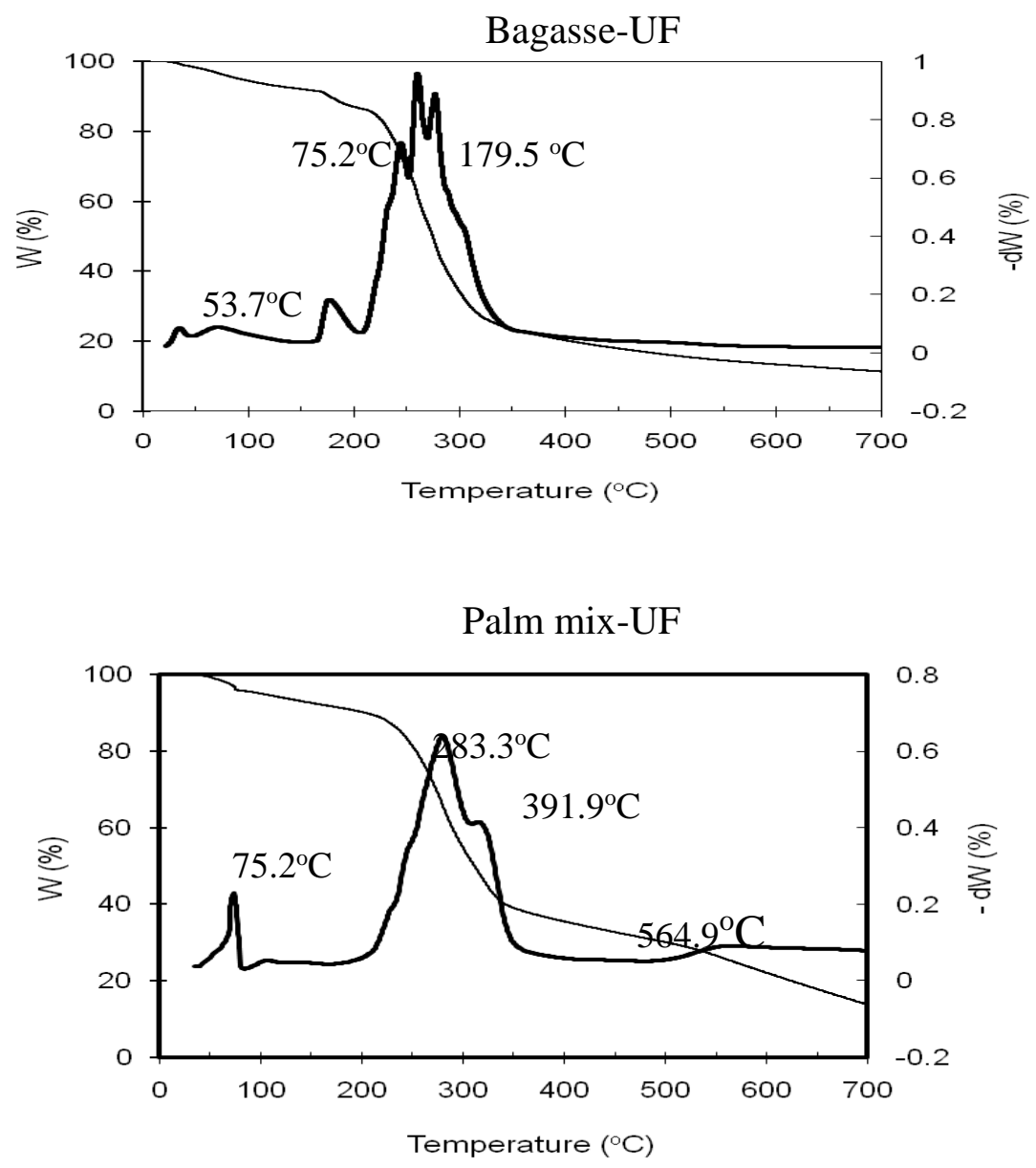

Palm Frond-UF

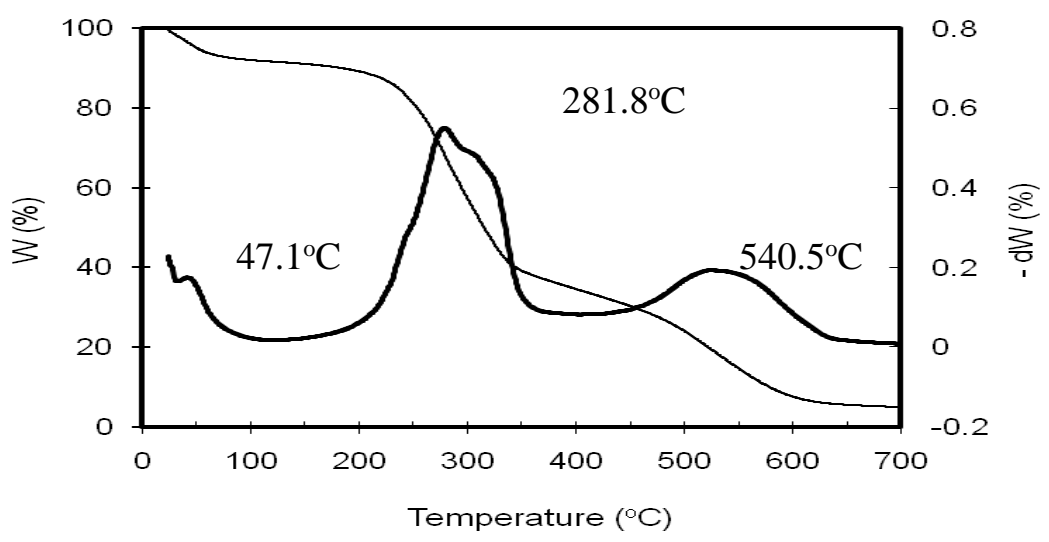

Figure 2. Thermo-gravimetric weight loss and derivative curves of palm frond fibers with UF in comparison with Bagasse fibers-UF. 
Table 6. TGA kinetic parameters of Bagasse- and palm components-UF samples and their

\begin{tabular}{|c|c|c|c|c|c|c|c|c|}
\hline $\begin{array}{l}\text { Sample } \\
\text { code } \\
\text { in chart }\end{array}$ & stage & $\begin{array}{l}\text { Temp. range } \\
{ }^{\circ} \mathrm{C}\end{array}$ & $\begin{array}{c}\text { DTG } \\
\text { peak } \\
\text { Temp., } \\
{ }^{\circ} \mathrm{C}\end{array}$ & "n" & $\mathrm{R}^{2}$ & SE & $\begin{array}{c}\mathrm{E}_{\mathrm{a}} \\
\mathrm{kJ} / \text { mole }\end{array}$ & $\begin{array}{c}\text { Wt. } \\
\text { remain \% }\end{array}$ \\
\hline \multicolumn{9}{|l|}{ Bagasse-UF } \\
\hline & $1^{\mathrm{st}}$ & r.t.-100.4 & - & - & - & - & - & 94.46 \\
\hline & $2^{\text {nd }}$ & 157.2-211.6 & 179.5 & 1.0 & 0.985 & 0.168 & 173.01 & 86.24 \\
\hline & 3rd & 211.6-390.5 & 261.5 & 2.0 & 0.980 & 0.230 & 127.25 & 20.82 \\
\hline Palm Mix- & $1^{\text {st }}$ & r.t- 106.5 & 75.2 & - & - & - & - & 94.57 \\
\hline \multirow[t]{3}{*}{ UF } & $2^{\text {nd }}$ & $164.8-302.7$ & 283.3 & 1.0 & 0.988 & 0.1087 & 84.82 & 53.33 \\
\hline & $3^{\text {rd }}$ & 302.7-328.4 & 391.9 & 1.5 & 0.985 & 0.146 & 117.90 & 40.22 \\
\hline & 4th & 461.3- 700.0 & 564.9 & 1.5 & 0.968 & 0.156 & 94.30 & 6.86 \\
\hline Palm Frond- & $1^{\mathrm{st}}$ & r.t- 104.33 & 33.7 & - & - & - & - & 91.97 \\
\hline \multirow[t]{2}{*}{ UF } & $2^{\text {nd }}$ & $150.4-398.5$ & 281.8 & 1.0 & 0.989 & 0.125 & 64.18 & 34.74 \\
\hline & $3^{\text {rd }}$ & $398.5-651.9$ & 540.5 & 0.5 & 0.982 & $0 . .124$ & 124.06 & 5.53 \\
\hline
\end{tabular}




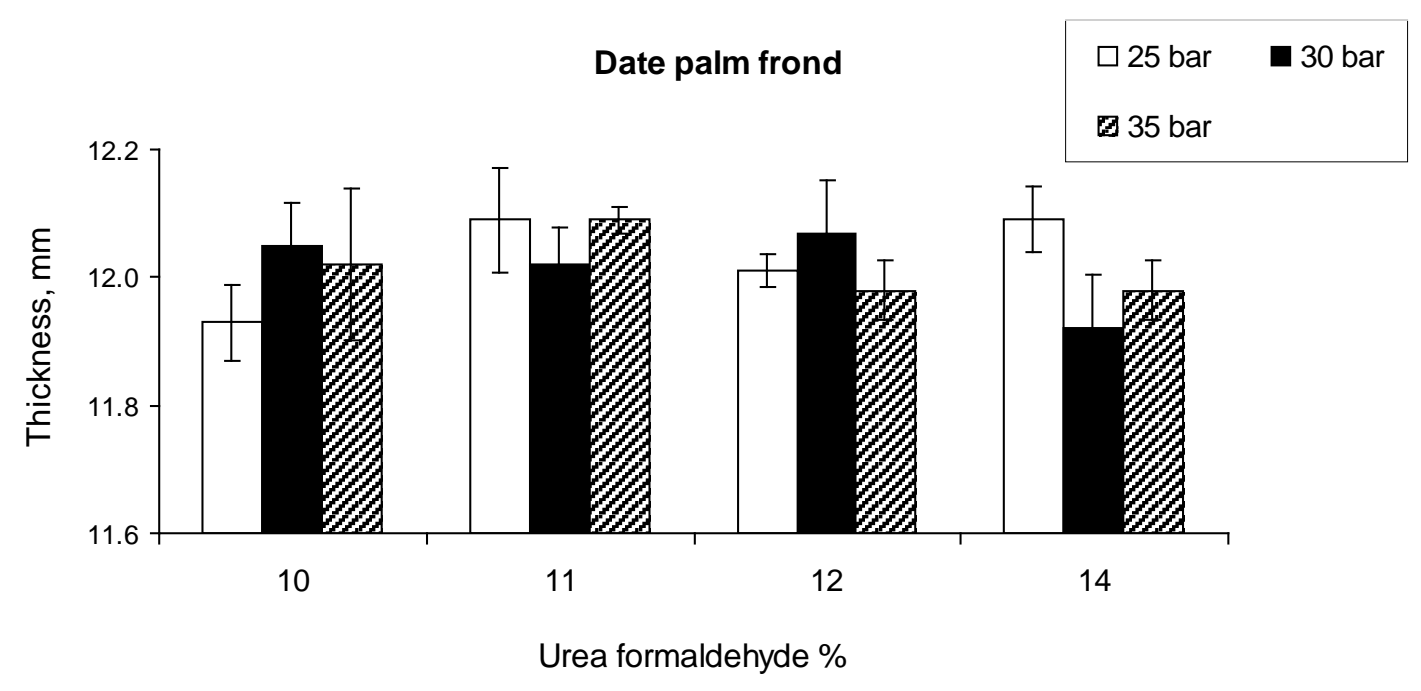

Sugare-cane bagasse

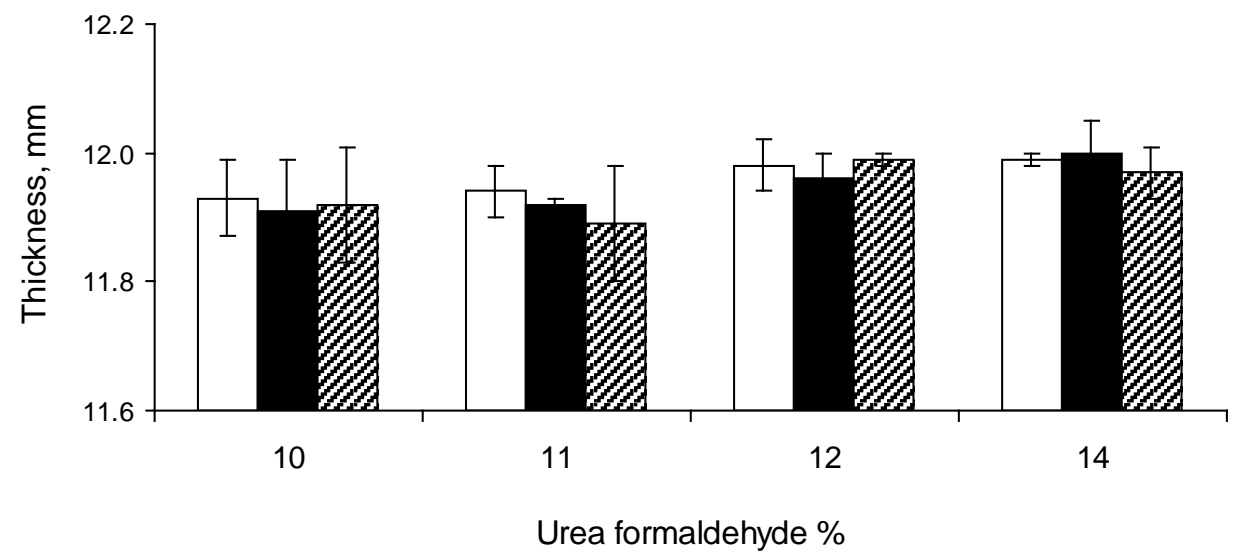

Figure 3. Variation of Thickness of MDF of palm frond and Bagasse fibers versus UF \%. 


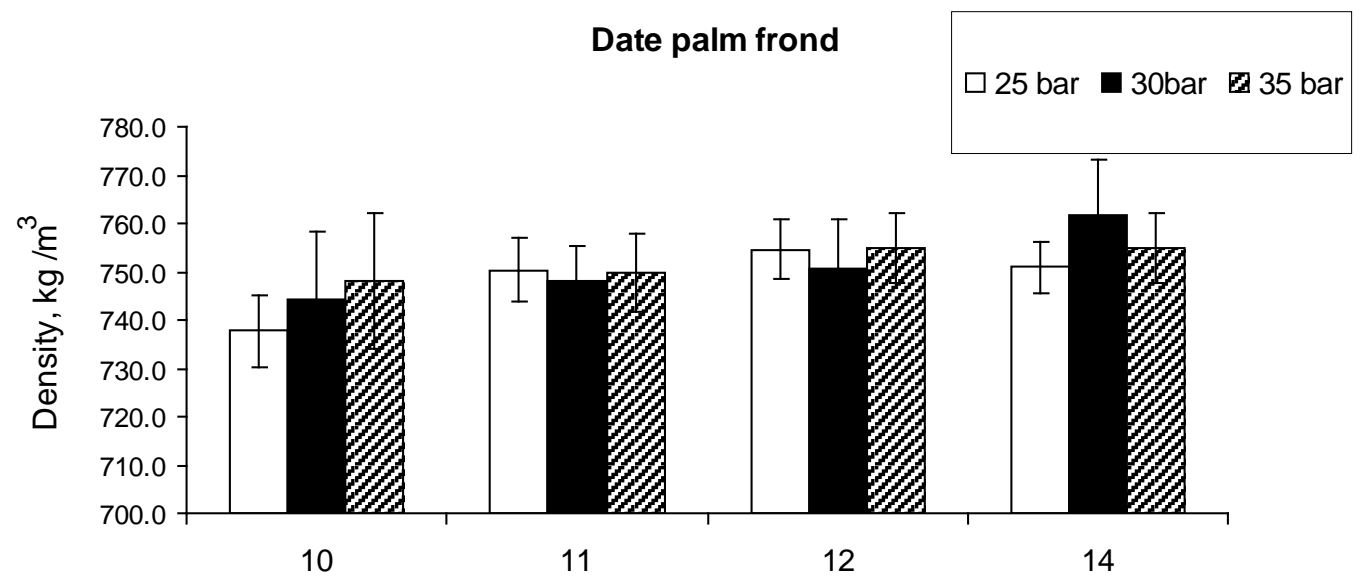

Urea formaldehyde \%

Sugar-cane bagasse

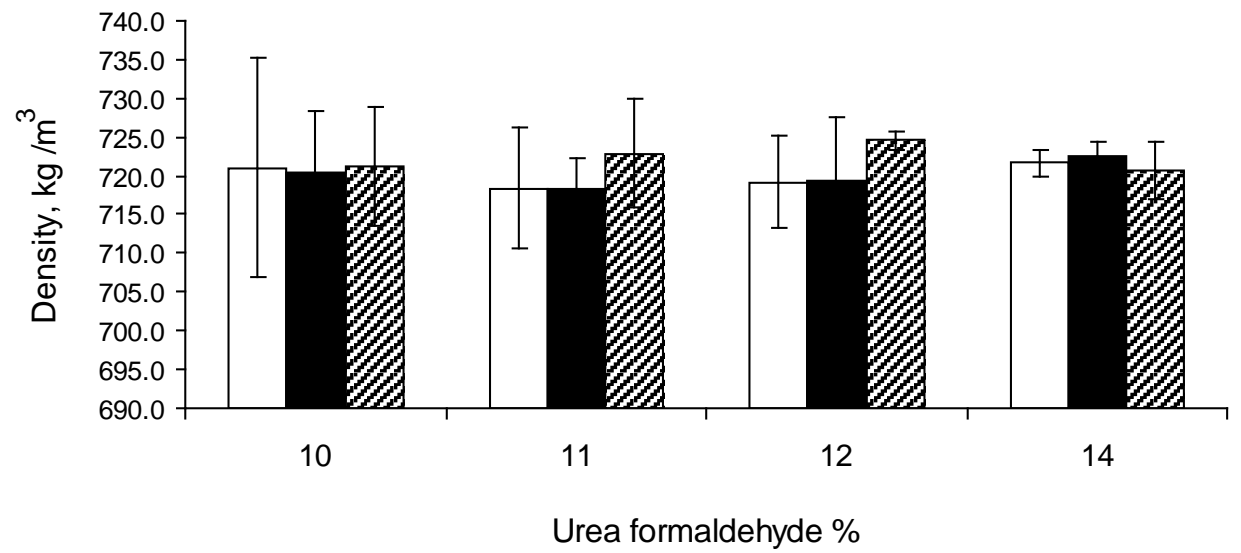

Figure 4. Variation of Gross density of MDF from palm frond and Bagasse fibers versus UF \% and specific pressure. 


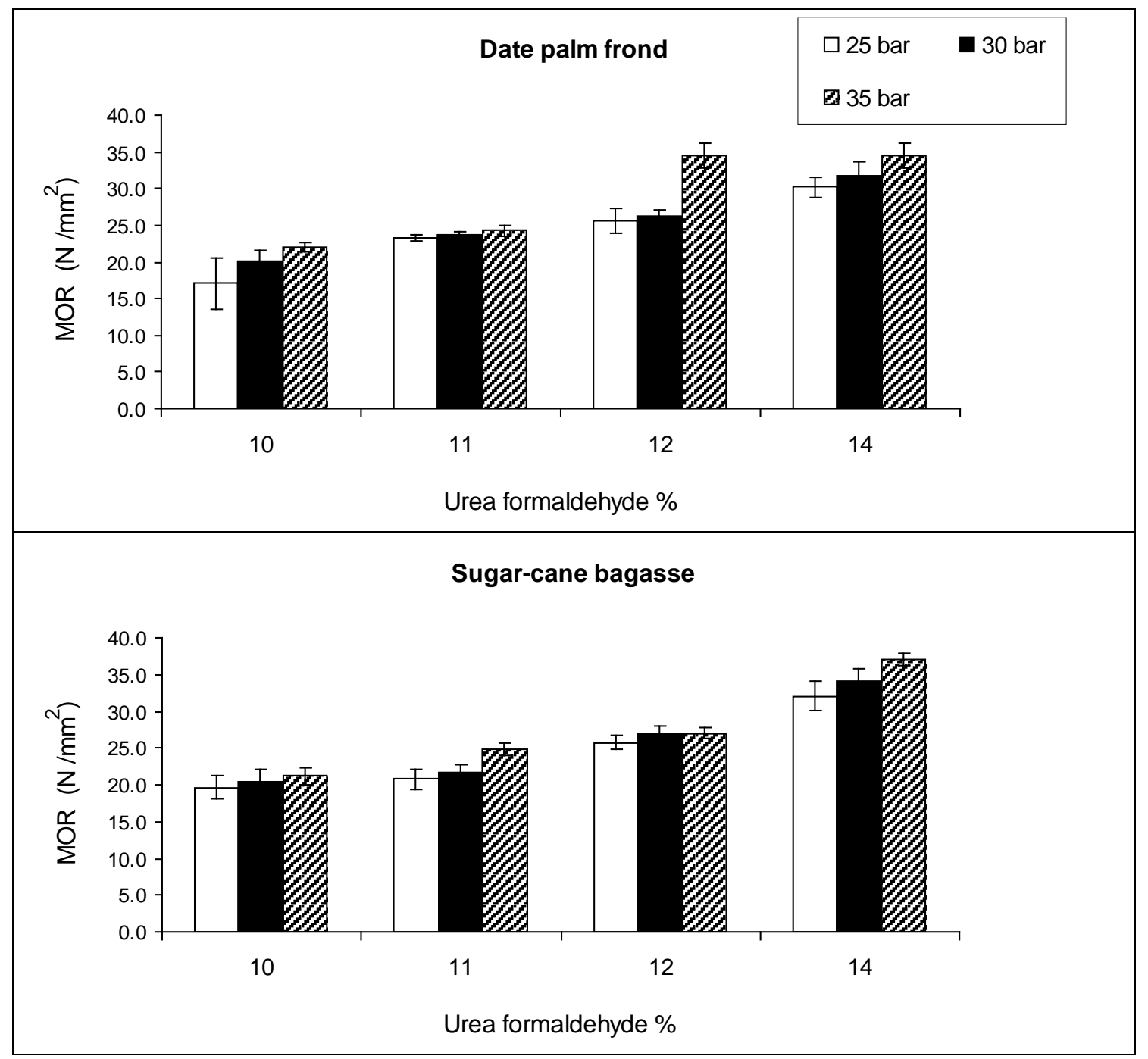

Figure 5. Variation of MOR of MDF from palm frond and Bagasse fibers versus UF $\%$ and specific pressure. 


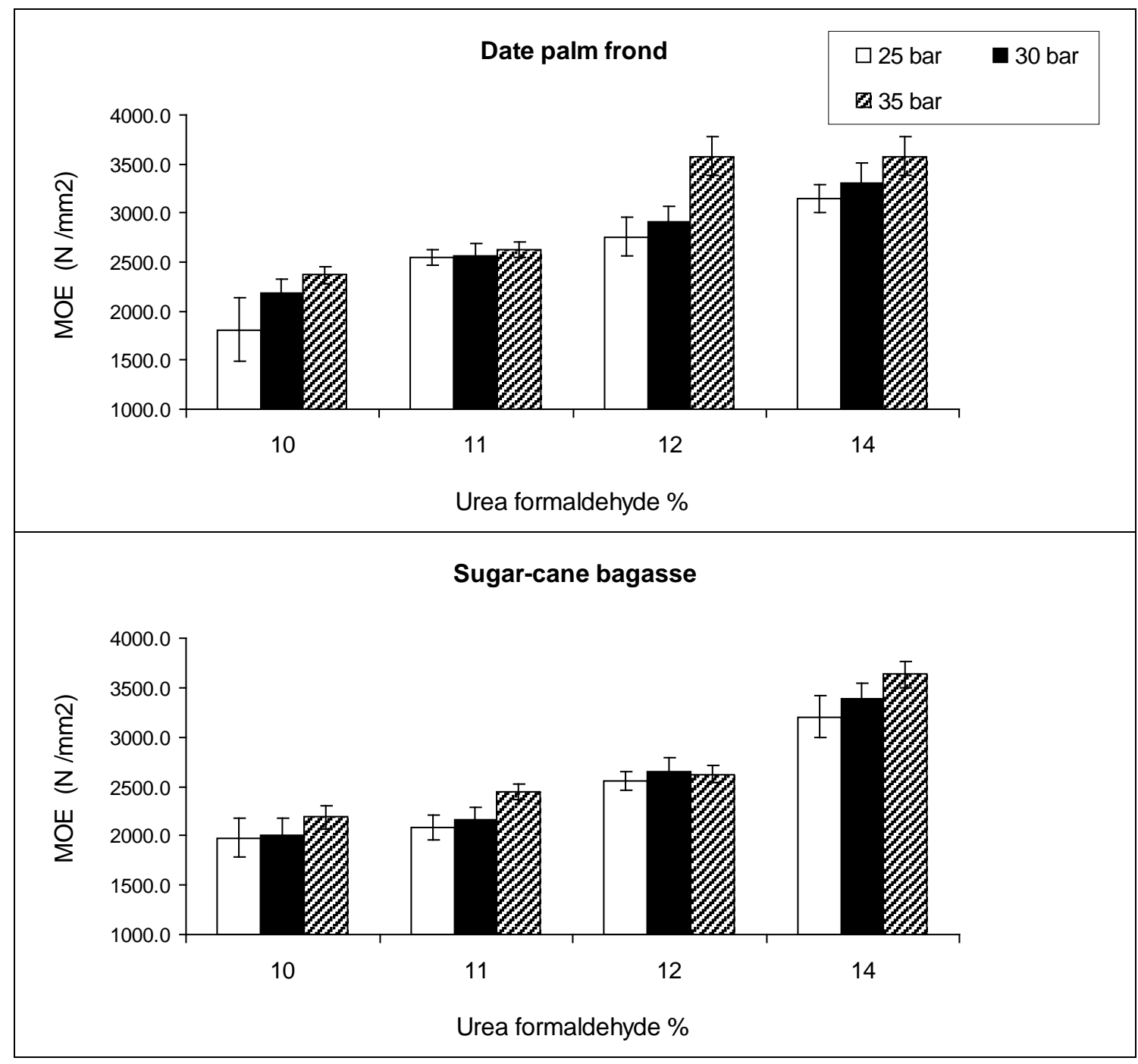

Figure 6. Variation of MOE of MDF from palm frond and Bagasse fibers versus UF $\%$. and specific pressure. 


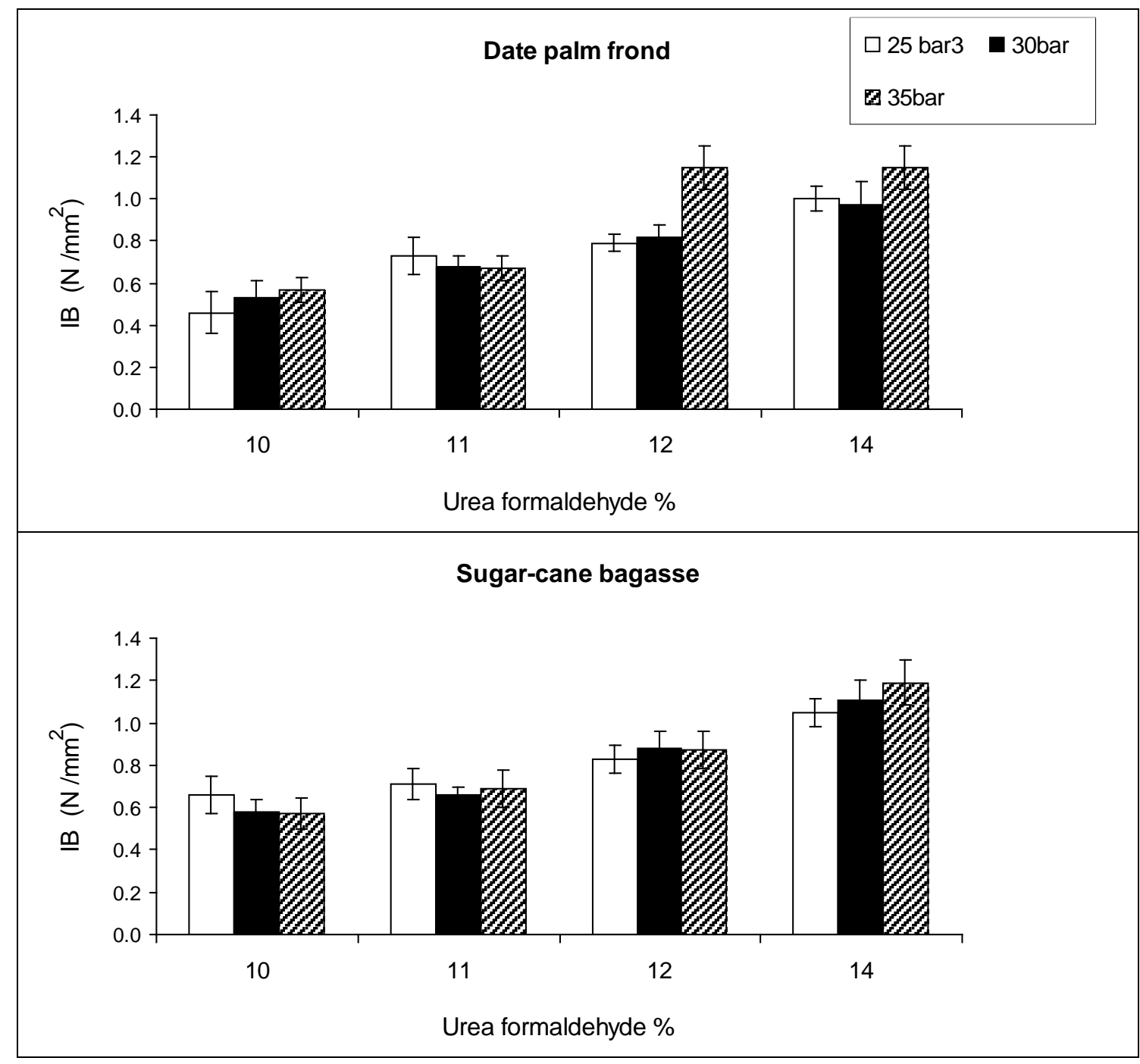

Figure 7. Variation of IB of MDF from palm frond and Bagasse fibers versus UF \% and specific pressure. 


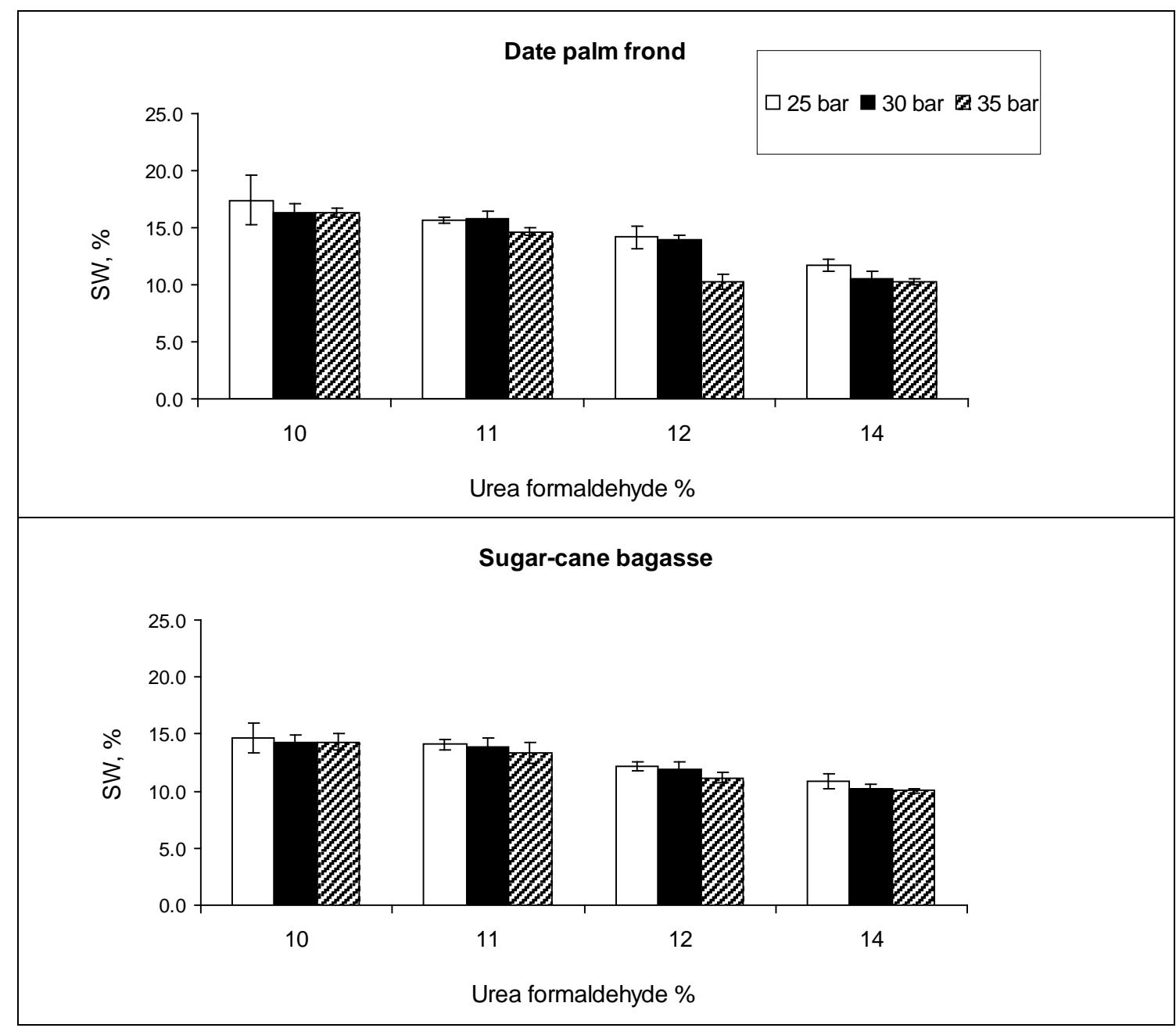

Figure 8. Variation of water swelling of MDF from palm frond and Bagasse fibers versus UF \% and specific pressure.

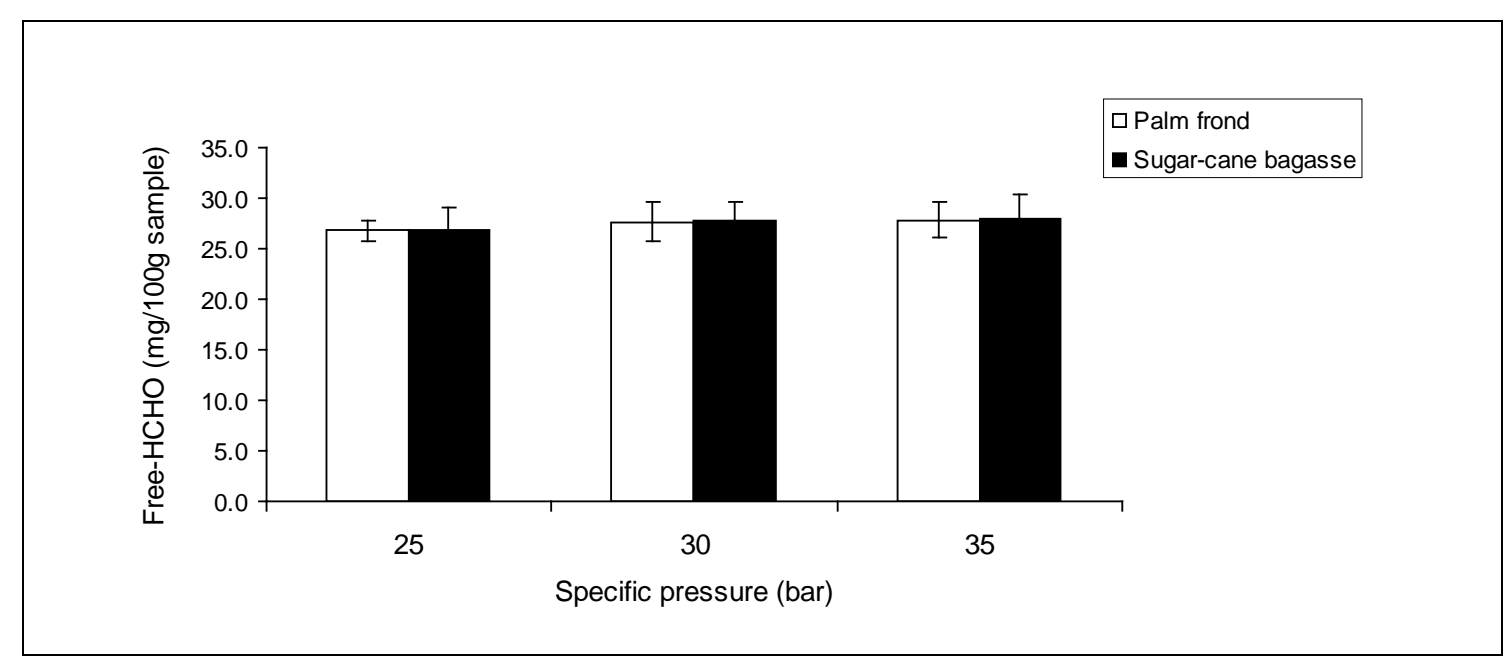

Figure 9. Free-HCHO of MDF palm frond and Bagasse fibers versus specific pressure 
With regard to non-isothermal thermogravimetric analysis, Figure 2 illustrates the TGA and DTG curves of the blend of palm components (palm mix) and palm frond resinated fibers with UF, in comparison with bagasse fibers-UF. Table 6 summarizes their kinetics parameters. Figure 2 shows that, there are three decomposition steps for bagasse-UF and Palm frond-UF resinated fibers. The first one at temperature lower than $100{ }^{\circ} \mathrm{C}$, indicates the evolution of adsorbed water, in addition to second and third steps, in the ranges from $150-399{ }^{\circ} \mathrm{C}$ and $211-652{ }^{\circ} \mathrm{C}$ corresponding to volatilization and carbonization (degradation of selected adhesive systems. The ranges of degradation stages of palm frond-UF $\left(150.4-398.5^{\circ} \mathrm{C}\right.$ and $\left.398.5-651.9^{\circ} \mathrm{C}\right)$ are greater than bagasse-UF (157.2-211.6 ${ }^{\circ} \mathrm{C}$ and $\left.211.6-390.5^{\circ} \mathrm{C}\right)$. Moreover, the peak temperature of these degradation stages in case of Palm frond $\left(281.8^{\circ} \mathrm{C}\right.$ and $\left.540.5^{\circ} \mathrm{C}\right)$ is higher than bagasse $\left(179.5^{\circ} \mathrm{C}\right.$ and $261.5^{\circ} \mathrm{C}$ ). This indicates the slowness degradation of resinated palm frond than bagasse (higher thermal stability). This observation is in agreement with that found by DSC which supports the curing of UF on palm frond fibers is occurred at longer time.

With regard to the blend of palm components (leaves + frond), it is observed that the volatilization is occurred in 2 stages with DTG peaks $283.3{ }^{\circ} \mathrm{C}$ and $391.9{ }^{\circ} \mathrm{C}$; while the carbonization stage with DTG peak at $564.9{ }^{\circ} \mathrm{C}$. This is probably related to the relatively higher extractives included palm leaves, which resist to some extent the role of steam and digestion process, and consequently it may affect the individualization of the fibers and interaction with UF. This extractive leads to increase the activation energy required for volatilization stage ( $\Sigma \mathrm{Ea}$ $=202.7 \mathrm{~kJ} / \mathrm{mole})$ than the case of palm frond $(64.2 \mathrm{~kJ} / \mathrm{mole}$ and bagasse $173.01 \mathrm{~kJ} / \mathrm{mole}$, respectively).

Based on the foregoing results of chemical constituents and thermal analysis, the palm frond was candidate as substrate for MDF production. Till it possible to use as alternative to commercial bagasse, the properties of MDF made from both fibers are compared.

\section{Properties of MDF}

The influence of preparation parameters, e.g., UF level and pressing pressure on the performance of MDF produced from palm frond and SCB fibers are illustrated graphically in Figures 3-9.

Figures 3 and 4 show that, changing the UF \% together with specific pressure provided board from palm frond and bagasse with thickness $\sim 12 \mathrm{~mm}$; while for board density in case of palm frond fibers is around $750 \mathrm{~kg} / \mathrm{m}^{3}$. This value is higher than that made from bagasse $(\sim 720$ $\mathrm{kg} / \mathrm{m}^{3}$ ); Figure 4. Higher board density is observed in case of board made from palm frond fibers at relatively higher UF\% (14\%) and applied specific pressure (35 bar) (it reached $762 \mathrm{~kg} / \mathrm{m}^{3}$ ). Static bending (MOR and MOE), and IB are greatly affected by changing both UF\% and specific pressure (Figures 5-7). At relatively lower UF\%, the specific pressure has a profound effect (improvement) on strength properties of MDF than higher ones. Where, for boards made from palm frond fibers, at $10 \% \mathrm{UF}$, changing the specific pressure accompanied by increasing in MOR, from 17 MPa to 22 MPa, MOE from 1811.6 MPa to 2368.8 MPa, and IB from 0.46 MPa to $0.57 \mathrm{MPa}$. While, on applying $14 \%$, the changes in MOR, MOE and IB with increasing the specific pressure from 25 bar to 35 bar are from 30 to $34 \mathrm{MPa}$, from 3153 to $3579 \mathrm{MPa}$, and from 1.0 to $1.15 \mathrm{MPa}$, respectively. A similar improvement is observed in case of SCB-based MDF. It is interesting to note that, both palm frond and bagasse fibers at $12-14 \%$ UF, and different specific pressure provided MDF boards fulfill the requirement of high grade MDF reported according to ANSI standard. In other words, the increasing in UF level was more significant on producing high quality MDF than specific pressure.

Results for the thickness swelling (SW) of the various MDF produced under the foregoing parameters are illustrated in Figure 8. It is clear that, the SW property of MDF decreased 
(improved) considerably as UF \% increased from 10\% to $14 \%$. Greater reducing in this property is observed at relatively lower specific pressure (25 bar), where SW decreased from $17 \%$ to $11 \%$ and from $15 \%$ to $10 \%$, in case of palm frond- and Bagasse-based MDF, respectively. Increasing the applied specific pressure to 35 bar, together with UF\% up to $14 \%$ provides SW value $10 \%$, in both types of fibers-based MDF. However, the changing in pressing pressure is not significant on free-HCHO of MDF produced, where its value between 25.88 to $27.95 \mathrm{mg} / 100 \mathrm{~g}$ board.

The explanation of the foregoing data may be ascribed to enhance the bond formation with increasing adhesive level and specific pressure, as well as due to the substrate constituents. Higher cellulose and hemicelluloses as well as lower extractives contents of sugar cane bagasse provide fibers easily adhered together during MDF formation, than palm frond fibers. Higher adhesive level and pressing pressure enhancing the affinity of palm frond fibers to response for adhering together during hot pressing.

For specifying the application of MDF produced from both fibers, as reported and based on ANSI and EN Standards, the MDFs produced from palm frond and bagasse fibers, especially with 12-14\% UF and Specific pressure 30-35 bar have higher values than the requirements for general purposes. These boards fulfill the requirements for strength and thickness swelling properties reported in ANSI Standard. According to TS and HCHO these boards are possible for load-bearing applications and specified as E2 type boards.

The ANOVA analysis was carried out for mechanical properties and physical properties as shown, for example, in Tables 7-8. These data show a significant differences between the static bending of MDF samples made from bagasse fiber , fronds fiber, and mixed frond and frond leaves, at different addition of UF adhesive. The levels of glue addition are slightly significant on properties of MDF boards made from mixed and frond fiber than those made from bagasse, with higher specific pressure of hot press.

For economic potential of using palm frond fibers, it will preserve the additional cost required for storage of bagasse and transportation. Moreover, this waste is available in many provinces, and persuades to construct wood Mills, without concerning on the Mills of upper-Egypt.

\section{Conclusions}

Due to the availability of date palm at different provinces, and for trial to minimize the economic and environmental impacts from storage of sugar-cane bagasse (SCB), as a substrate for production $\mathrm{MDF}$, in this article we evaluated the palm fibers components on the quality of produced MDF. The performance of palm-based MDF was also evaluated, in comparison with traditional prepared SCB-based MDF. The results of chemical constituents of date palm components (leaves and fronds), their average weights, as well as Fibers-UF interactions (via DSC and TGA studies) lead us to recommend the use of date palm frond (DPF) in production of MDF. DPF-based MDF especially with 12-14\% UF and specific pressure 35 bar have acceptable properties as compared to those produced from sugar-cane bagasse. It is static bending (MOR and MOE), internal bond strength (IB) fulfilled the high requirements in mechanical and thickness swelling properties of ANSI and EN standards. Where, their values were $34.4 \mathrm{MPa}$, 3579.2 MPa, 1.15 MPa and 10.2 \%, respectively.

\section{Acknowledgment}

The authors are grateful to Nag-Hamady Co. for Fiberboard-Quena, Egypt for providing the raw materials and equipment for the experimental study. 


\section{References}

[1] A. Kargarfard, A.J. Latibari, The performance of corn and cotton stalks for medium density fiberboard production, Bioresources 6 (2011) 147-57.

[2] A.A. Adam, A.H. Basta, H. El-Saied, Performance of bagasse-based medium density fiberboard produced from different steam digestion retention times. Forest Product Journal 62-5 (2012) 400-405. https://doi.org/10.13073/0015-7473-62.5.400

[3] M. Akgul, A. Toslughu, Utilizing peanut husk in the manufacture of medium density fiberboards, Bioresource Technology, 99 (2008) 5590-5594.

https://doi.org/10.1016/j.biortech.2007.10.041

[4] M. Akhtar, W.R. Kenealy, E.G. Horn, R.E. Swaney, J.E. Winandy, Method of making medium density fiberboard, US Patent No: US 2008/0264588 A1, 2008.

[5] ANSI 208.2., American National Standardization Institute. Medium Density Fiberboard, 1994.

[6] ASTM D1037, Standard test for evaluation the properties of wood-based and particle panel materials, American society and materials, Philadeplia, PA.: ASTM D1037-94, 1994.

[7] ASTM E1690, Determination of ethanol extractives in bagasse, in Annual book of ASTM Standards, Philadelphia, PA: American Society for Testing and Materials 11.05, E1690, 2003.

[8] N. Ayrilmis, J.E. Winandy, Effect of post heat treatment on surface characteristics and adhesive bonding performance of MDF, Materials and Manufacturing Processes 24 (2009) 594599. https://doi.org/10.1080/10426910902748032

[9] A.H. Basta, H. El-Saied, New approach for utilization of cellulose derivatives metal complexes in preparation of durable and permanent colored papers, Carbohydrate. Polymers 742 (2008) 301-308. https://doi.org/10.1016/j.carbpol.2008.02.021

[10] A.H. Basta, V. Fierro, H. El-Saied, A. Celzard, Effect of Deashing Rice Straws on their derived Activated Carbons produced by Phosphoric Acid Activation, Biomass and Bioenergy 35 (2011) 1954-1959. https://doi.org/10.1016/j.biombioe.2011.01.043

[11]A.H. Basta, H. El-Saied, J.E. Winandy, R. Sabo, Preformed amide-containing biopolymer for improving the environmental performance of synthesized urea-formaldehyde in Agro-fibre Composites, Journal of Polymers and the Environment 19-2 (2011) 405-412.

https://doi.org/10.1007/s10924-011-0286-4

[12]A.H. Basta, H. El-Saied, O. El-Hadi, C. El-Dewiny, Evaluation of rice straw-based hydrogels for purification of wastewater. Polymer Plastic Technology and Engineering 52-11 (2013) 1074-1080. https://doi.org/10.1080/03602559.2013.806548

[13] A.H. Basta, H. El-Saied, V.F. Lofty, Performance assessment of deashed and dewaxed rice straw on improving the quality of RS-based composites, RSC Advances 4-42 (2014) 2179421801. https://doi.org/10.1039/c4ra00858h

[14]A.H. Basta, H. El-Saied, V.F. Lotfy, Performance of rice straw-based composites using environmentally friendly polyalcoholic polymers-based adhesive system, Pigment and Resin Technology 42-1 (2013) 24-33. https://doi.org/10.1108/03699421311288733 [15]A.H. Basta, H. El-Saied, E.M. Deffallah, Optimising the process for production of high performance bagasse-based composites from rice bran-UF adhesive system, Pigment and Resin Technology 43-4 (2014) 212-218. https://doi.org/10.1108/prt-08-2013-0077 
[16] A.H. Basta, H. El-Saied, E.M. Deffallah, Effects of denaturisation of rice bran and route of synthesis of RB-modified UF adhesive system on eco-performance of agro-based composites, Pigment and Resin Technology 54-3 (2016) 172-183. https://doi.org/10.1108/prt-04-2015-0037 [17]E. Ciannamea, P.M. Stefani, R.A. Ruseckaite, Medium Density fiberboard from rice husks and soybean protein concentrate-based adhesive, Bioresource Technology 101 (2010) 818-25. https://doi.org/10.1016/j.biortech.2009.08.084

[18]A.W. Coats, J.P. Redfern, Kinetic parameters from thermogravimetric data, Nature 201 (1964) 68-72. https://doi.org/10.1038/201068a0

[19] Y. Copur, C. Gular, C. Tascioglu, A. Tozluoglu, Incorporation of hazelnut shell and husk in MDF production, Bioresource Technology 99 (2008) 7402-7406.

https://doi.org/10.1016/j.biortech.2008.01.021

[20]D.E. El Nashar, S.L. Abd-El-Messieh, A.H. Basta, Newsprint paper waste as a fiber reinforcement in rubber composites, Journal of Applied Polymer, Science 91-5 (2004) 34103420. https://doi.org/10.1002/app.13726

[21]H. El-Saied, M.H. Fadl, A.H. Basta, Properties of bagasse hardboard made by in-situ formation of phenol-lignin formaldehyde resin, Polymers \& polymer composites 4-7 (1996) 519522.

[22]H. El-Saied, A.H. Basta, M.E. Hassanen, H. Korte, A. Helal, Behaviour of Rice-Byproducts and Optimizing the Conditions for Production of High Performance Natural Fiber Polymer Composites, Journal of Polymers and the Environment 20-3 (2012) 838-847. https://doi.org/10.1007/s10924-012-0439-0

[23]EN 120, The European Standard for “determination of free formaldehyde in wood-based panels Perforator method, 1992.

[24]H.R. Faraji, Investigation on properties of medium density fiberboard (MDF) produced from bagasse: M.Sc. Thesis, Tarbiat Modares University, Faculty of Natural Resources and Marine Science, 1998.

[25] N.A. Fathy, V.F. Lotfy, A.H. Basta, Comparative study on the performance of carbon nanotubes prepared from agro-and xerogels as carbon supports. Journal of Analytical and Applied Pyrolysis 128 (2017) 114-120. https://doi.org/10.1016/j.jaap.2017.10.019

[26] S. Halvarsson, H. Edlund, M. Norgren, Properties of MDF based on wheat straw and melamine modified urea- formaldehyde (UMF) resin, Industrial Crops and Products 28 (2008) 37-46. https://doi.org/10.1016/j.indcrop.2008.01.005

[27] Y. Hossein, Canola straw as a bio-waste resource for medium density fiberboard manufacture, Waste Management 29-10 (2009) 2644-2648.

https://doi.org/10.1016/j.wasman.2009.06.018

[28]A. Istek, D. Aydemir, H. Eroglu, Surface properties of MDF coated with calcite/clay and effects of fire retardants on surface properties, Maderas Ciencia y tecnología 14-2 (2012) 135144. https://doi.org/10.4067/s0718-221x2012000200001

[29] G. Jayme, P. Sarten, Über die quantitative bestimmung von pentosen mittels bromwasserstoff-sauer, Naturewise 28-52 (1940) 822-823. https://doi.org/10.1007/bf01489045 [30] S. Lee, T.F. Shupe, C.Y. Hse, Mechanical and physical properties of agro-based fiberboard. Holz-als-Roh-und-Werkstoff 64 (2006) 74-79. https://doi.org/10.1007/s00107-005-0062-z 
[31]X. Li, Z. Cai, J.E. Winandy, A.H. Basta, Effect of Oxalic Acid and Steam Pretreatment on the Primary Properties of UF-bonded Rice Straw Particleboards, Industrial Crops and Products 33 (2011) 665- 669. https://doi.org/10.1016/j.indcrop.2011.01.004

[32]H. Mahmoudi, G. Hosseininia, H. Azadi, M. Fatemi, Enhancing date palm processing marketing and pest control through organic culture, J Organic Systems 3-2 (2008) 29-39.

[33] E. Roffael, C. Behn, D. Krug, A. Weber, C. Hartwig-Gerth, G. Gräfe, UF- und PMDIDoppelbeleimung bei Faserplatten,. Holz-Zentralblatt 137 (2011) 1216-1217.

[34] V. Sivakumar, M. Asaithambi, P. Sivakumar, Physico-chemical and adsorption studies of activated carbon from agricultural wastes, Advances in Applied Science Research 3-1 (2012) 219-226.

[35] TAPPI Test Method T429, Determination of cellulose, In TAPPI Test Methods. Atlanta, GA: Technical Association of the Pulp and Paper Industry, 2012.

[36] TAPPI .Test Method T222, Determination of acid insoluble lignin, In TAPPI Test Methods. Technical Association of the Pulp and Paper Industry, 1998.

[37] V.K. Thakur, A.S. Singha, M.K. Thakur, Graft copolymerization of methyl acrylate onto cellulosic biofibers: Synthesis, characterization and applications. Journal of Polymers and the Environmen, 20-1 (2012) 164-174. https://doi.org/10.1007/s10924-011-0372-7

[38] V.K. Thakur, A.S. Singha, M.K. Thakur, Surface modification of natural polymers to impart low water absorbency. International Journal of Polymer Analysis and Characterization, 17 (2012) 133-143. https://doi.org/10.1080/1023666x.2012.640455

[39] V.K. Thakur, A.S. Singha, M.K. Thakur, In-air Graft copolymerization of Ethylacrylate onto Natural Cellulosic Polymers, International Journal of Polymer Analysis and Characterization, 17 (2012) 48-60. https://doi.org/10.1080/1023666x.2012.638470

[40] V.K. Thakur, M.K. Thakur, R.k. Gupta, Graft copolymers of natural cellulose for green composites, Carbohydrate Polymers, 104 (2014) 87-93.

https://doi.org/10.1016/j.carbpol.2014.01.016

[41]H.R. Taghiyari, P. Nouri, Effect of nano-wollastonite on physical and mechanical properties of medium density fiberboard. Maderas. Ciencia y tecnología 17-4 (2015) 833-842. https://doi.org/10.4067/s0718-221x2015005000072

[42]H.R. Taghiyari, P. Nouri, Effect of wollastonite on physical and mechanical properties of medium density fiberboard (MDF) made from, Wood fibers and camel-thorn. Maderas. Ciencia y tecnología 18-1 (2016) 157-166. https://doi.org/10.4067/s0718-221x2016005000016

[43]L.F. Wise, M. Murphy, A.A. D’assiece, Chlorite holocellulose, its fractionation and bearing on summative wood analysis and on stiudes on the hemicellulosi. Paper Trade Journal 122-2 (1946) 35-43.

[44]X.P. Ye, J. Julson, M. Kuo, A. Womac, D. Myers, Properties of medium density fiberboard made from renewable biomass, Bioresource Technology 98 (2007) 1077-1084.

https://doi.org/10.1016/j.biortech.2006.04.022

[45]H. Younesi-Kordkheili, A. Pizzi, Properties of plywood panels bonded with ionic liquidmodified lignin-phenol-formaldehyde resin, The Journal of Adhesion, http://dx.doi.org/10.1080/00218464.2016.1263945, 2017 